\title{
Child and Family Benefits to Halt Hungary's Population Decline, 1965-2020: A Comparison with Polish and Romanian Family Policies
}

\section{Ildikó Szántó}

\begin{abstract}
Based on the long-term, demographic forecast, Hungary faces a significant population loss. This paper examines the continuing low level of Hungarian fertility, as well as the marked decline of population due to out-migration beginning in the mid-2000s. First, I will discuss the role governmental family policies play in halting fertility decline before 1989, the demographic post-transitional period of 1960-1980 and the past thirty years since 1989. Second, this paper particularly aims to highlight the impact of the new family policy since 2010, a reverse redistribution of resources from poor to the better-off families which did not result in a marked growth of birth rates. The new family benefits possibly further contribute to the existing polarization of Hungarian society without altering Hungary's demographic data. Finally, the paper also compares the recent changes of family policies in Poland, Hungary and Romania since 2004.
\end{abstract}

Keywords: low birth rates, family policy, population loss, out-migration

Biography: Ildikó Szántó received her M.A. degree in History from Macquarie University, N.S.W. She has taught interdisciplinary courses focusing on the ideological movements of the twentieth century in East-Central Europe at the Budapest University of Economic Sciences, Pázmány Péter Catholic University and the Budapest Business School. ildikoszanto3@gmail.com

First, I will refer to my earlier paper, "Problems of a Declining Hungarian Birth Rate: A Historical Perspective" (Szántó 2014; See Appendix, Tables 1 and 2) which outlined that after World War II Hungary was the first country in Europe where the level of fertility declined below a level of simple population replacement, conventionally measured as 2.1 births per woman. Hungarian demographers view the long-term impact of the continuous decrease in the birth rate that occurred beginning in the mid-1950s less as a specific Hungarian problem than a stage that all advanced societies go through as a part of modernization. The cause of such a general decrease in birth rate might have been explained by the cumulative effects of economic and social changes and/or the large-scale adoption of new values, with an emphasis on a secular outlook on life as accompanying factors in the process of modernization which applied to society at large (Andorka 1987: 282-286). 
Szántó, Ildikó. "Child and Family Benefits to Halt Hungary’s Population Decline, 1965-2020: A Comparison with Polish and Romanian Family Policies." Hungarian Cultural Studies. e-Journal of the American Hungarian Educators Association, Volume 14 (2021): http://ahea.pitt.edu DOI: 10.5195/ahea.2021.429

Concurrent with the political consolidation of the Kádár government and the impact of the economic reforms carried out in the late 1960s, on the whole living standards improved, particularly in families with more than one wage earner per family (Crampton 1994: 317, Romsics 1999: 440, 485). The Kádár era was also a period marked by open debates discussing numerous social issues, a circumstance mostly unheard of in other socialist countries. Furthermore, the debate about population decline was possibly the most intense one (Szántó 2015). The decreasing fertility rate of the 1960s and consequent smaller families forced the government to work out a long-term population policy. Provided by the state to all families with children the családi pótlék ['family allowance'] was a general monthly financial support that began with the birth of the child and continued as long as the child lived in the same household and attended school. In 1965, the family allowance was significantly increased. From 1967, the introduction of the gyermekgondozási segély or GYES ['Childcare Allowance'] was available from the birth of the child up to the age of three and included the universal, sixmonth maternity leave. Access to GYES provided added financial support for parents and represented a fixed-sum (about twenty five percent of women's average earnings) for parents in the low-income range. By 1969, GYES was tied to one year of previous employment. In the case of three children, GYES amounted to forty percent of the average industrial monthly wage in order to compensate for lost earnings. At the time, it was among the longest forms of maternity leave and the most favorable childcare benefit available in the world. The aim of the government's comprehensive population policy was to ensure at least the future replacement of the parent's generation with the target of an average of 2.3 children born to each family (Andorka 1987: 193,288.).

The welcome effects of this generous population policy, the family allowance and the Childcare Allowance was a marked increase in the fertility rate from 1966, although this rate was only to fall from the mid-1970s onwards. The pro-natalist policy of the Childcare Allowance encouraged women to remain home and possibly have a second child within three years. If the mother had been employed prior to birth, the employer was obliged to keep the mother on the payroll for up to three years after the birth of a child while seventy percent of her salary was payable during the first six months of her maternity leave. In spite of the various and generous family benefits (amounting to fourteen percent of the gross domestic product of Hungary at the time), the number of live births began to decrease again from 1977 and continued to fall to the level of 1960 (Romsics 1999: 485).

By 1981, the fertility rate continued to decline markedly below the level necessary for the long-term reproduction of the population. The reasons for the falling birth rate in the 1980s were, first of all, the age groups which were most likely to contract marriages were smaller, a certain proportion of marriages had been delayed and the proportion of divorces increased among women of child-bearing age by some fifty percent (Klinger 1981: 24). In addition, compared to previous decade, real wages fell substantially as economic growth contracted and young people faced a far more difficult situation in both housing and employment. As the birth rate reached a critically low figure in 1982, the socialist government launched another form of financial support, the gyermekgondozási díj, GYED ['Childcare Benefit'], which targeted working parents in an attempt to compensate them for lost earnings until the child was two years old. This employment-based childcare benefit was introduced in 1985 and amounted from sixty-five to seventy-five percent of an individual's average earnings. The duration originally lasted up to the child's first birthday before being extended to eighteen months in 1986 and then two years in 
Szántó, Ildikó. "Child and Family Benefits to Halt Hungary’s Population Decline, 1965-2020: A Comparison with Polish and Romanian Family Policies." Hungarian Cultural Studies. e-Journal of the American Hungarian

Educators Association, Volume 14 (2021): http://ahea.pitt.edu DOI: 10.5195/ahea.2021.429

1987. To be eligible, the recipient must have been employed for at least 365 days during the previous two years (Andorka 1987: 287-288,338; Darvas and Szikra 2017: 215; Drew 2005: 15).

Other than the previous earnings-related parental benefits, the Childcare Benefit included an added one month of full pay for the mother prior to the birth of the child. Furthermore, a fiveday paternity leave was introduced beginning in 1985 as well as access to the Childcare Allowance for students who became parents during their full-time, tertiary studies. These students were also eligible for a ten-percent increase in the family allowance and an extended paid sick leave benefit during a child's illness (Kapitány 2008: 59; Gábos 2018: 201). The impact of the generous Childcare Benefit affected the accepted family model of two children between 1985 and 1996 and sixteen percent of two-child families had a third child. Thus, the increased fertility of the two-child families was significant, especially in the context of the unfavorable societal and economic conditions brought about by the regime change in the beginning of the 1990s, when one-and-a-half million workplaces were lost (Kapitány 2008: 57; Gödri et al 2014: 20).

In the 1990s, welfare costs were reduced, but these cutbacks did not affect family benefits and both GYES and GYED were maintained. Moreover, a third form of childcare benefit, the gyermeknevelési támogatás or GYET ['Child Rearing Support'] became available in 1993. Although receiving access to GYET was independent of employment, the main pre-condition was for parents to be raising three or more children below the age of fourteen, in which the household's youngest member was between three and eight years of age. In 1995, GYET was extended to one- and two-child families and (similar to the Childcare Allowance) the flat-rate cash benefit equaled the minimum amount of the old age pension at the time. GYET was introduced during the most intensive period of socio-economic and institutional changes, when Hungary's gross domestic product declined approximately eighteen percent, the inflation rate was roughly twenty-three percent and unemployment was above twelve percent (Dövényi 1994: 396; Ferge et al 1997: 10, 27). Subsequently, the universal earnings-related benefit during parental leave and the flat-rate-benefit family policy became a subject of political debate. In 1996, cash benefits were abolished and both GYES and GYED were amalgamated into one benefit as means-tested family benefits, a measure taken to exclude those with higher income while simultaneouly aiming to reduce unemployment (https://www.theglobaleconomy.com/Hungary/Unemployment_rate/ International Monetary Fund 2019: 165; Darvas, Szikra 2017: 225-228).

As a result of the dramatic decline of the fertility rate to 1.29 by 1999, the first Orbán government (1998-2002) reverted to the pre-1995 model as means testing was abolished and the1998 Family Support Act of LXXXIV (as well as its Amendment in 2001) considerably extended the number of working hours during parental leave while simultaneously broadening the eligibility of parental leave and family benefits for grandparents and guardians. Both the Childcare Allowance as well as Child Rearing Support became universal and its monthly sum was the equivalent of the minimal sum of the old age pension, (HUF 23,200 in 2004, HUF 24,700/€98,8 in 2005 (Darvas, Szikra 2017: 236). At the same time, the government introduced a comprehensive tax-relief system in 1999 which directly sought to raise fertility, namely third births. The main beneficiaries were parents raising three or more children who had taxable income. Both measures (the universal flat-rate benefit, the equivalent of the minimal sum of the old age pension and the tax allowance) were to encourage "good" families to have a third child as the Prime Minister, Victor Orbán stressed in his 2000 speech bearing the slogan of "Three children, three rooms and four wheels." The tax allowance benefited parents with medium- or 
Szántó, Ildikó. "Child and Family Benefits to Halt Hungary’s Population Decline, 1965-2020: A Comparison with Polish and Romanian Family Policies." Hungarian Cultural Studies. e-Journal of the American Hungarian Educators Association, Volume 14 (2021): http://ahea.pitt.edu DOI: 10.5195/ahea.2021.429

higher-range income (which usually meant those possessing a medium or higher educational attainment) in an attempt to encourage them to have a third child. In spite of the financial benefits offered by the child-rearing support, it was less appealing for a mother to stay at home as her professional advancement would be affected. The family tax relief may have not only stimulated third births in such families, but also encouraged mothers to return to the labor market since their workplace was guaranteed (Sarnyai 2018: Inside Hungary's Family Support System | NewsPortal.HU: October 12, 2018).

In 2000, when Hungary's gross domestic product returned to its 1989 level, combined family income reached a level that made it possible to take the full advantage of the tax concessions for a three-child family (Spéder 2017: 5). The full financial benefit for a three-child family equaled almost one fifth, and by 2001 rose to fifty-one per cent of an average women's earnings. In contrast to the earlier policy, these new, pronatalist measures assisted better-off families while a large proportion of families with children in the lowest third of the income distribution were unable to claim the full tax rebate. Seventeen percent of families could not even obtain the tax allowance as they did not have sufficient income: another six percent of families only partly qualified for the tax relief. The combination of the comprehensive family benefits and the tax allowance primarily helped medium- and high- income groups, where it was possible that the birth of a third child had a positive impact (Spéder et al. 2020: 44,50, 51; Darvas, Mózer 2004: 81; Gábos et al 2009: 218).

Following the first Orbán government (1998-2002), the socialist-liberal coalition governments (first the Medgyessy government (2002-2004) succeeded by Gyurcsány (20042008) government) aimed to focus on a complex welfare system that would protect all families, including labor, housing, education, childcare and the provision of free meals and textbooks for children in need. As it turned out to be financially non-sustainable from 2003 onwards, the Medgyessy government abandoned the generous, state-subsidized housing loan introduced by the previous government and tax exemptions for mortgage repayment for families (Hegedüs et al 2009: 33; Makszin, Bohle 2020: 15). The Medgyessy government increased the family allowance by twenty percent while also adding a thirteenth month of an extra cash benefit in order to compensate for the eroded purchasing value of the family allowance and childcare benefits. The Childcare Allowance and Child Rearing Support became a part of the universal family allowance and was extended to support children until the age of twenty-four, in the case that these dependents were still attending tertiary education. From 2004, the Gyurcsány government (2004-2009) advocated a "Just family system" with an emphasis on reducing child poverty and specifically embraced the needs of single parents, disabled children and large families. The parental leave provided by the Childcare Allowance was reduced from three to two years and eligibility for Child Rearing Support began from the age of two, as both benefits were fused into családi pótlék ['family allowance']. The previously introduced tax rebate by the first Orban government became means-tested and was applied among families with more than two children, although in practice it was gradually phased out. The universal cash benefit of the family allowance was doubled for those in need. The generous rendszeres gyermekvédelmi kedvezmény or RGYK ['Regular Child Protection Benefit'] was extended. From 2004 it also included regular free midday meals during the school year as well as in-school holidays, a cash benefit for textbooks and cash support twice a year for children living in families with multiple disadvantages stemming from extreme poverty.

In 2005, the Gyurcsány government announced a new housing program, the Fészekrakó program ['Nesting Program'] to aid families or single parents below the age of thirty who could 
Szántó, Ildikó. "Child and Family Benefits to Halt Hungary’s Population Decline, 1965-2020: A Comparison with Polish and Romanian Family Policies." Hungarian Cultural Studies. e-Journal of the American Hungarian Educators Association, Volume 14 (2021): http://ahea.pitt.edu DOI: 10.5195/ahea.2021.429

not afford a deposit for purchasing a home or chose to apply for assisted rental accommodation (Hegedüs et al 2009: 36). Furthermore, the introduction of the National Strategy Plan, Legyen jobb a gyermekeknek ['Making Things Better for Our Children'] aimed at eliminating child poverty in cooperation with the progressive EU welfare agenda (Bauer et al 2015:7). The 2008/2009 global financial crisis as well as the internal political problems of the Gyurcsány government gave way to an interim government, the "crisis manager" Bajnai cabinet. As a result of the gravity of the economic situation, the Bajnai government froze the családi pótlék ['family allowance'], but did not cut other family benefits (Darvas, Szikra 2017: 222, 229-230; Rat, Szikra 2015: 227).

The family policy introduced by both socialist-liberal coalitions (the Medgyessy and Gyurcsány governments) realized that cash support alone is insufficient to affect the continuous fertility decline. Instead, an attempt was made to maintain a generous safety net for low-income families, promote part-time employment during parental leave and focus on eliminating child poverty while providing more affordable housing for disadvantaged young couples (Thévenon 2011: 58; Makszin, Bohle 2020: 18). The socialist-liberal coalition government abandoned its anti-poverty programs as a result of the 2008/2009 fiscal crisis, at which time the gross domestic product fell by almost eight percent and the rate of unemployment rose. The Bajnai government's austerity measures (especially the reduced family allowance) hit the poorest and most vulnerable strata of the population (Szikra 2014: 2).

The family policy of the second Orbán government (2010-2014) was stated in the 2011 constitution, Magyarország Alaptörvénye ['Hungary's Fundamental Law'] which defined the family as a relationship between a man and a woman in marriage only and excluded any other forms of family relationships. Furthermore, the Családok védelméröl ['Family Protection Act'] stated that "the promotion of families is distinct from the system of social provision for the needy. The state provides support primarily to the "responsible upbringing of children." It thus refers to families who have sufficient resources and excludes families with social and economic problems while disregarding children and families who suffer from various forms of deprivation. The pronatalist, conservative view of the policy makers directed resources only to those families that it defined as "responsible working families" (Darvas, Szikra 2017: 223, 226; 2011. CCXI. law). In 2011, a new taxation policy entailing a uniform sixteen-percent personal income tax replaced the previous progressive income taxation system. The flat rate of personal income tax was reduced to fifteen percent from 2016. Combined with very generous child tax credits, this change benefited forty percent of middle- and upper-middle class families, especially those with more than two children. Low-income earners, i.e., forty percent of child-rearing families, lost out. For another twenty percent of families, the tax credits made no difference. In order to utilize the maximum of the tax allowance, a gross income approaching twice the average monthly income of 1,600 EUR was needed in 2012 (Szikra 2014: 7). Meanwhile, the family allowance remained at the 2008 level, regardless of the needs of the family. From 2011, the statutory age of education was reduced from eighteen to sixteen years of age, thus no child would get any benefit over the age of sixteen unless the child was attending school. Moreover, numerous regulations were tied to the eligibility of the családi pótlék ['family allowance']: in case of truancy, if a child was missing more than fifty classes per term, i.e., missed five days unexcused without a medical certificate, the family allowance could be revoked. Other than this factor, the often arbitrary regulations such as that of an "untidy" home environment could also lead to having the family allowance canceled. The rules were and are complicated and non-transparent while penalties or loss of benefits could last up to fourteen months in spite of the fact that the family allowance was 
Szántó, Ildikó. "Child and Family Benefits to Halt Hungary’s Population Decline, 1965-2020: A Comparison with Polish and Romanian Family Policies." Hungarian Cultural Studies. e-Journal of the American Hungarian Educators Association, Volume 14 (2021): http://ahea.pitt.edu DOI: 10.5195/ahea.2021.429

the only secure, fixed income for families living in acute poverty. Parents who are unemployed, employed as part of the government's public works scheme or working in the grey economy could not utilize tax allowances, a factor that consequently excluded more than three point five million individuals, i.e., approximately forty percent of families who did not have sufficient income to qualify for a family tax rebate (Kolosi, Fábián 2016:13; Albert et al 2014: 9; Appendix, Tables 3 and 4). In contrast, the better-off families benefited from the Gyermekgondozási díj, GYED extra ['Childcare Benefit extra'], that entered into force on January 1,2014. Modified in 2016, GYED extra allowed mothers to go back to the labor market after their child had reached six months of age. Those who qualified for GYED extra benefits were also able to keep seventy percent of their previous earnings with an upper income limit up to the second birthday of the child (Szikra 2014: 9,11; Rat and Szikra 2015: 227; Szikra 2018: 8, 9; Makay 2015: 57).

The following Orbán governments (2014-2018, 2018-present) offered various financial support for families, such as an increased, one-time maternity benefit of 64,125 HUF in 2017 at the birth of a child and income-tax exemption for life for women with four or more children. Beginning in 2020, free, in-vitro fertilization (IVF) treatment for couples at state-run clinics was also added. Possibly the most important family assistance was the családi otthonteremtési kedvezmény, CSOK ['Family Housing Program'] launched in 2015. The size of state support, a lump sum issued as a part of CSOK, is maximum ten million forints (27,800 Euros) as well as a subsidized loan, all of which depends upon the number of children the couple plans to have. This support can be put toward the purchase of newly built houses or apartments provided that the couple agrees to have one, two, three or four children. In the case that this agreement is not kept, both the lump sum and the loan has to be repaid according to the agreed terms of the contract (MTI-Hungary Today: May 22, 2019).

The Orbán regime's family policy markedly differed from the Medgyessy and Gyurcsány, socialist-liberal coalition governments. Contrary to the values of a welfare state and the European Social Model, Viktor Orbán proposed to build a "work-based society" (Szikra 2018: 5). One of the potential aims of earlier family policies, the elimination of child poverty, vanished from Orbán's agenda. Although from 2011 family policy aimed to counter negative demographic trends and support families with children, the generous tax rebate only benefited the top twenty percent: fewer than two million families counted among the "winners" who could utilize the significant family tax credits. The two bottom income deciles, the "drifters," the precariat class (eighteen percent or more than one point five million families) and the disadvantaged, the unskilled, the Roma (altogether represent twenty percent or two million of the Hungarian population) lost out even if they had three or more children. In total, about three point five million of the total population represented the real losers of the new family tax policy (Appendix,Tables 5 and 6). The impact of the innovative housing program, CSOK, distorted the housing market even further as the rapid rise of property values excluded medium- or lowincome earners. Instead of offering cheaper rental accommodation for young families, the program emphasized home ownership (Darvas, Szikra 2017: 226; Szikra 2018: 9; Kolosi, Fábián 2016: 13). In spite of the various pronatalist, "familialist" policies propagated by the Orbán governments during the last decade, these approaches have failed to halt the population decline of an aging Hungarian society. Although the sluggish growth in fertility rates improved from 1.38 to 1.54 between 2013 and 2018, the total population of Hungary decreased to below ten million while the yearly population loss has hovered between thirty and forty thousand individuals, i.e. the equivalent of a size of an average town in the country (Appendix,Table 8; 
Szántó, Ildikó. "Child and Family Benefits to Halt Hungary’s Population Decline, 1965-2020: A Comparison with Polish and Romanian Family Policies." Hungarian Cultural Studies. e-Journal of the American Hungarian Educators Association, Volume 14 (2021): http://ahea.pitt.edu DOI: 10.5195/ahea.2021.429

Waterbury 2020:12; Walker 2020: https://www.theguardian.com/world/2020/mar/04/babybonuses-fit-the-nationalist-agenda-but-do-they-work. March 4).

The yearly population loss was also linked to increasing outward migration, which has become one of the most concerning social problems especially since 2010. According to reports by the Organization of Economic Cooperation and Development (OECD), an estimated six hundred thousand Hungarian citizens (approximately five percent of Hungary's population) are currently employed abroad. The real size of emigration can only be estimated on the basis of the number of registered Hungarian citizens who have permanently settled in Western Europe. Before 2010, Hungarian outward migration was less pronounced: until recently, its structure was rather different in comparison to most of the neighboring countries, especially Poland or Romania. Before 2010, Hungary had not figured among high-emigration countries, such as Romania or Bulgaria; by 2012 Hungary "caught up" to those in the region. Although the long term impact and implications of outward migration are not yet known, based on data from the Hungarian Central Statistical Office [KSH], it has been suggested that every sixth Hungarian child is born abroad (OECD 2018.; Vég April 10,2019). Moreover, Hungary is the only country where the migration rate of graduates has also risen by an average of 0.7 percentage points annually. Other than the long term, demographic effect of outward migration, its immediate impact on health care or sectors such as hospitality, construction and manufacturing have been apparent for some time (Hárs 2019: 140,149; Horváth and Kiss 2015: 91; Mrav 2018:142).

A comparison of family policies employed in the three former communist states of Poland, Hungary and Romania show continuity in the pre-1990 period as the three states share Bismarckian legacies as regards maternity care, protection of the traditional family as well as all major benefits which were extended during the communist period. Unlike Poland, Hungary developed and maintained a generous and extensive social policy, with a particular focus on the declining fertility rate and childcare during the decades before 2004. In contrast, Poland neglected family support and childcare until recently. Hungary has been a leader in the development of kindergartens and achieved major progress in the area of family policy during the 1970s and 1980s, when both Poland and Romania lagged far behind (Szikra 2011: 364; Inglot, Szikra, Rat, Part I 2011:52; Inglot 2020: 3).

From the 1950s until 1989, Polish family benefits included maternity insurance, family allowances, childcare parental leaves and birth grants as a part of employment and wages that were labelled as "family benefits." By the 1990s, this approach became known as "pro-family" or "family" policy." Prior to 1990, the introduction of major family policy reforms invariably coincided with political and economic crisis, such as the unpaid childcare (parental) leave in 1968 under Gomułka's government, followed by the Gierek regime's plan to build an advanced "socialist welfare society" (Inglot 2008: 166) or in 1981 during Jaruzelski regime when the negotiated wage increase derived from an agreement between the government and the Solidarity movement. By 1981, one-time childbirth grants and a limited, eighteen-month, means-tested parental leave payment was available for parents. In contrast to the Hungarian family policy, the Polish family policy was characterized by stagnation and a slow development of childcare facilities, as nurseries and kindergarten were placed at the lowest priority in comparison to health care and elementary schooling even during the period of high fertility that occurred before 1989. Following the regime change, Poland kept its inherited family policy the longest, leaving it unchanged until 1995 (Inglot, Szikra, Raţ, Part I 2011: 53,55).

By the late 1990s and early 2000s, Poland faced a serious demographic challenge as its fertility rates had been dropping steadily since 1989 . The low fertility rate therefore became a 
Szántó, Ildikó. "Child and Family Benefits to Halt Hungary’s Population Decline, 1965-2020: A Comparison with Polish and Romanian Family Policies." Hungarian Cultural Studies. e-Journal of the American Hungarian Educators Association, Volume 14 (2021): http://ahea.pitt.edu DOI: 10.5195/ahea.2021.429

national issue which demanded reforms. Consequently, the "Program of Pro-Family Policy of the State" was launched: for the first time, the government listed fertility increase as a major objective and also emphasized self-help and subsidiarity. In addition, the family policy proposed child tax credits and extended maternity leaves and special assistance for large families while supporting basic state assistance for the poor, including a guaranteed minimum income. The family benefits law of 2003 integrated all basic cash payments (except maternity) under one simplified umbrella and increased maternity leave from sixteen to twenty-six weeks. The new program also aimed to assist families with a per capita income that fell below approximately twenty-five percent of an average wage in 2003, an amount to be adjusted upwards every few years. The discussion on the suggested family policy coincided with the EU accession negotiations between 2000 and 2004, a crucial period for Poland as domestic welfare issues had to be brought into compliance with European goals of gender equality, social inclusion, labor activation and regional development (Inglot, Szikra, Rat, Part I 2011: 9-10, 15, 53). In 2013, Poland registered a fertility rate at 1.29 , compared to Hungary at 1.35 , when both countries remained far below the EU-28 average of 1.55. Meanwhile, the median age of Hungary's population increased from 37.4 to 41.3 years. In Poland, during the same period, the median age rose even faster from just 33.4 to 39.5 . The Polish demographic crisis was further exacerbated by mass migration (predominantly of younger people) to the west, reaching a high of 2.5 million: more than 2 million Poles moved to EU states in 2016 (Inglot 2020:3).

The reactions of the Hungarian and the Polish governments to the alarming decline of fertility rate differed. Entitled Az Új Baby Boom. A középosztály gyermekvállalási forradalma ['The New Baby Boom: A Revolution in Middle Class Fertility'], the second Orbán government's reform program offered substantial tax breaks for higher- and middle-income families and based its family policy on a disproportional redistribution of funds from the poor to the wealthy (Appendix. Table 7). Poland, however, embarked on a different path of family policy, even though this route also focused on the continuing fertility decline (Inglot 2020: 9; Szikra 2018: 9; Rat, Szikra 2015: 226; Walker March 4, 2020). In Hungary, Orbán's centralized, decision-making power left little room for civic bodies: in Poland, the discussion surrounding the family program was a complex process of interaction carried out among political parties, nongovernmental bodies and individuals with considerable influence in the formulation of family policy before 2016. Under the two prime ministers, Donald Tusk and Ewa Kopacz, the Civic Platform retained key elements of the 2007 Family Policy Program drafted by its predecessor, Law and Justice (PiS). They also introduced new benefits for mothers based on the extension of the available maternity leave to a full year (an extra twenty-six weeks) of parental leave that could be shared by both mother and father. In 2015, it was the Law and Justice (PiS) Party, which announced the major benefit known as $500+$. This new family policy granted each family with two or more children a monthly, tax-free benefit of 500 zloty (ca.120 Euros), which was separate from the means-tested family allowance, with the latter comprising an additional support of about twelve percent of the average gross wage. Provided their income fell below 800 zloty (200 Euros) per person within the household, single mothers with one offspring were also included. Beginning in 2016, this program was expanded to include all children in the 500+. As a result of the reform, child poverty decreased by as much as fifty to seventy percent in comparison to the pre-2016 period. Large families with three or more children as well as those lower-income families who had faced the greatest losses following the transition to a market economy after the regime change have benefited the most from the new family policy (Inglot 2020:15). 
Szántó, Ildikó. "Child and Family Benefits to Halt Hungary’s Population Decline, 1965-2020: A Comparison with Polish and Romanian Family Policies." Hungarian Cultural Studies. e-Journal of the American Hungarian Educators Association, Volume 14 (2021): http://ahea.pitt.edu DOI: 10.5195/ahea.2021.429

In comparison, Romania's family policy bears some similarities to Poland as both nations possessed a large rural population and poorly developed infrastructure before 1990. However, the impact of an influence originating from Stalinism was what set Romania apart from Poland or Hungary. Romania's family policy was characterized by Soviet-style, symbolic financial rewards for the "hero mothers" raising large families, even though the country inherited prewar short maternity leaves with the development of public nurseries and kindergartens. At the height of Stalinism, birth grants were limited to the tenth and later the seventh child: these pronatalist family policies continued till the regime change (Decree 106/1950119). The accelerated process of industrialization that characterized the grand vision of the nationalist Ceaucescu regime (1974-1989) needed a large workforce, including working women, while childcare facilities were limited and overcrowded. Decree 770/1966 prohibited abortion and withdrew contraceptives from the market while also introducing a celibacy tax, a financial penalty for childless couples. Divorce fees were additionally increased. According to Decree 771/1966, criminal sanctions awaited not only persons who committed abortions, but also those who assisted in the procedure or even refrained from reporting. In comparison to Hungary and Poland, family policies in Romania had low priority and remained underdeveloped until the 1990s (Inglot, Szikra, Rat, Part I. 2011: 41-44). Following the collapse of the communist regime in December 1989, the region's new governments faced the legacy of pronatalism, the plight of abandoned children in run-down state institutions, child poverty and much higher fertility rates in rural areas and particularly among the Roma minority. Throughout the 1990s, family policies responded to the political demands to "repair" the damage caused by the communist regime and focused on children's rights and child protection. Meanwhile, the deprivation of Roma and rural families actually worsened after 1990. Similar to Hungary, both universal family allowance for school-aged children (from 1993) and the means-tested support allowance (from 2010) were dependent upon school attendance (Chiriac May 21, 2015, January 13, 2020; Inglot, Szikra, Rat Part II 2011: 69).

To summarize the changes in family policy from the last two decades, since the early 2000s family policy reforms in Poland, Hungary and Romania reflect similar, yet distinctive problems. In the case of Poland and Hungary, the declining fertility rate and the demographic impact of outmigration of their, mostly young citizens to more developed, EU countries exacerbated the median age of the population, thereby bringing about an aging population. As a result of these demographic concerns, both the Polish and Hungarian governments primarily focused on family policies that consisted of cash transfers, albeit with a different emphasis. The objectives of the comprehensive Polish family reform was to increase the fertility rate and reduce child poverty. In contrast, from 2010 the Hungarian family policy focused only on the "better-off families" found in the upper and middle strata of society and disregarded child poverty (Inglot 2020: 3; See Appendix, Table 6).

Finally, the question of whether various forms of financial support are sufficient to affect birth rates must be weighed. The long term effectiveness of family policy interventions on fertility is difficult to prove, even in the more stable contexts of Western Europe with more predictable economic growth (Spéder 2020: 50). Both previous and more recent pronatalist family measures increased fertility rates both in Hungary and Poland, although these were only slight increases that meant more the stabilization of fertility rates without altering the overall demographic picture. Other than the ideological commitment, the question remains of whether the current social expenditure of family policies (five percent of the gross domestic product in case of Hungary and three percent in Poland) can be maintained in the future (Inglot 2020: 6,18, See Appendix, Table 9). 
Szántó, Ildikó. "Child and Family Benefits to Halt Hungary’s Population Decline, 1965-2020: A Comparison with Polish and Romanian Family Policies." Hungarian Cultural Studies. e-Journal of the American Hungarian Educators Association, Volume 14 (2021): http://ahea.pitt.edu DOI: 10.5195/ahea.2021.429

Despite the distinct, historical features of the family policies of the three former socialist states, as member states of both the European Union and the OECD (The Organization for Economic Co-operation and Development), they demonstrate a closer relationship with the objectives laid out in EU family policy. In his systematic analysis of the OECD countries, the sociologist, Olivier Thévenon, who focuses on reconciling family and working life and maintains that families are the cornerstone of society, placed the issue of increasing birth rates last. He prioritized poverty reduction in the form of benefits to lower-income families, cash benefits, fiscal transfers, tax advantages and other benefits that should precede targeted pronatalist measures. Similarly, Thévenon listed parental leave entitlement, childcare provision, part-time and flexible worktime regulations for mothers as well as high-quality childcare services as top priorities for family policies (Thévenon 2011: 69). In short, the demographic issue of a falling birthrate is part of a larger sociological question.

\section{Works Cited}

Albert, Fruzsina, Dávid, Beáta. Kristóf, Luca. Róbert, Péter and Szabó, Andrea. n.d. "Osztálylétszám 2014 ['Class Enumeration 2014']; Mapping the Hungarian Class Structure" 2014: 1-17. Institute for Political Science, Centre for Social Sciences 19892014: Twenty-five Years After. What Has Happened to the Societies in Central and Southeast Europe Since the Fall of the Iron Curtain? https://static.unigraz.at/fileadmin/veranstaltungen/twenty-five-yearsafter/presentations/ClassMapGrazPRobert.pdf

Albert, Fruzsina., B. Dávid, Z. Kmetty, L. Kristóf, P. Róbert and A. Szabó. 2017. "Mapping the Post-Communist Class Structure: Findings from a New Multidimensional Hungarian Class Survey." East European Politics and Societies, 32.3.: 544-565.

Andorka, Rudolf. 1987. Gyermekszám a fejlett országokban. ['Determinants of Fertility in Advanced Countries']. Budapest: Gondolat Könyvkiadó.

Bauer, Zsófia, Husz, Ildikó and Szontagh, Éva.2015. "Handling Long-Standing Inequalities with Short-Term Projects: Some Results and Challenges of the Implementation of the 'Give Kids a Chance' Programme." Review of Sociology. 25(4):5-29

Chiriac, Marian. 2015. Balkan Insight. May 21. https://balkaninsight.com/2015/05/21/romania-doubles-child-benefit/

------- 2020. Romania Insider. January 13. Balkan Investigative Reporting Network (BIRN) https://www.romania-insider.com/pm-options-child-allowance-jan-2020

Crampton, R. J. 1994. Eastern Europe in the Twentieth Century. New York: Routledge. Darvas, Ágnes and Mózer, Péter. 2004. "Kit támogassunk?" ['Whom to Support?']. Esély ['Opportunity'] 6:64-99.

Darvas, Ágnes and Szikra, Dorottya. 2017."Családi ellátások és szolgáltatások” ['Family Benefits and Services']. Magyar Társadalom-és Szociálpolitika 1990-2015. ['Hungarian Society and Social Policy 1990-2015']. Ed. Zsuzsa Ferge. Budapest: Osiris: 215-254.

Dövényi, Zoltán. 1994. "Transition and Unemployment: The Case of Hungary." GeoJournal 32. 4: 393-398.

Drew, Eileen. 2005. "Parental Leave in Council of Europe member States". Directorate General of Human Rights. Strasbourg, 1-15. Study on parental leave (coe.int) 
Szántó, Ildikó. "Child and Family Benefits to Halt Hungary’s Population Decline, 1965-2020: A Comparison with Polish and Romanian Family Policies." Hungarian Cultural Studies. e-Journal of the American Hungarian

Educators Association, Volume 14 (2021): http://ahea.pitt.edu DOI: 10.5195/ahea.2021.429

Ferge, Zsuzsa. 2017. Magyar Társadalom-és Szociálpolitika 1990-2015 ['Hungarian Society and Social Policy 1990-2015'] Budapest:Osiris.

Ferge, Zsuzsa. 2019. “+ 30 esszék a közelmúltról és a közel jövőrôl” " [‘Thirty Plus Essays about the Recent Past and the Near Future']. Ed. György Földes. Budapest: Napvilág Kiadó: 73-94.

Ferge, Zsuzsa, Sik, Endre, Róbert, Péter and Albert, Fruzsina. 1997. Societies in Transition. International Report on the Social Consequences of the Transition. http://zsuzsa.ferge.hu/docs/social_costs_of_transition.pdf

Gábos, András, Gál, Róbert I. and Kézdi, Gábor. 2009. "The Effects of Child-Related Benefits and Pensions on Fertility by Birth Order: A Test on Hungarian Data." Population Studies. 63.3:215-31.

Gábos, András. 2018. "Hungary Country Note." International Review of Leave Policies and Research. Eds, S. Blum, A. Koslowski, A. Macht and P. Moss. http://www.leavenetwork.org/lp_and_r_reports/

Gödri, Irén, Soltész, Béla and Bodacz-Nagy, Boróka. 2014.“Immigration or Emigration Country? Migration Trends and their Socio-Economic Background in Hungary: A Longer-Term Historical Perspective." Papers on Population, Family and Welfare 19:174.

Hárs, Ágnes. 2019. "Increasing Outward Migration-Opportunities, Hopes and Labor Market Impacts." Hungarian Social Report. Ed. István György Tóth. TÁRKI Social Research Institute:138-159.

Hegedüs, Orsolya, Eszeny, Nóra and Kiss-Molnár, Enikő. 2009. Housing Needs in Hungary. Metropolitan Research Institute. Budapest: Városkutatás kft.:1- 48.

Horváth, István and Kiss,Tamás. 2015. "Depopulating Semi-Periphery? Longer Term Dynamics of Migration and Socioeconomic Development in Romania." Demográfia English Edition, Hungarian Demographic Research Institute.58.5: 91-132.

Inglot, Tomasz. 2008. Welfare States in East Central Europe, 1919-2004. Cambridge: Cambridge UP.

Inglot, Tomasz, Szikra, Dorottya and Raţ, Cristina. 2011. "Continuity and Change in Family Policies of the New Democracies: Comparison of Poland, Hungary and Romania." Part I: Institutional Legacies and Path Dependence in Family Practice - 1945 to 2000. National Council for Eurasian and East European Research University of Washington. Seattle, WA.: 1-77. https://www.ucis.pitt.edu/nceeer/2011_825-10_Inglot1.pdf

Inglot, Tomasz, Szikra, Dorottya and Raţ, Cristina. 2011. "Continuity and Change in Family Policies of the New Democracies: Comparison of Poland, Hungary and Romania" Part II: Path Dependence and Path Departure in Family Policies Since 2000. National Council for Eurasian and East European Research University of Washington. Seattle, WA.:1-73. https://www.ucis.pitt.edu/nceeer/2011_825-10_Inglot2.pdf

Inglot, Tomasz. 2020.“The Triumph of Novelty over Experience? Social Policy Responses to Demographic Crises in Hungary and Poland since EU Enlargement" East European Politics and Societies and Cultures 20.10: 1-21. https://doi.org/10.1177/0888325419874421journals.sagepub.com/home/eep

International Monetary Fund. 2019.The Main Economic Indicators in 1980-2018. Report for Selected Countries and Subjects 5:165. 
Szántó, Ildikó. "Child and Family Benefits to Halt Hungary’s Population Decline, 1965-2020: A Comparison with Polish and Romanian Family Policies." Hungarian Cultural Studies. e-Journal of the American Hungarian

Educators Association, Volume 14 (2021): http://ahea.pitt.edu DOI: 10.5195/ahea.2021.429

https://www.imf.org/external/pubs/ft/weo/2019/02/weodata/weorept.aspx?sy=1980\&ey= $2024 \& \mathrm{scsm}=1 \& \mathrm{ssd}=1 \&$ sort $=$ country $\& \mathrm{ds}=. \& \mathrm{br}=1 \& \mathrm{pr} 1 . \mathrm{x}=88 \& \mathrm{pr} 1 . \mathrm{y}=15 \& \mathrm{c}=944 \& \mathrm{~s}=\mathrm{NG}$ DP_RPCH,PPPGDP,PPPPC,PCPIPCH,LUR,GGXWDG_NGDP\&grp=0\&a $=$

Kapitány, Balázs. 2008. A “GYED-HATÁS”: Az 1985 és 1996 közötti családtámogatási rendszer termékenységre gyakorolt hatása A népesedéspolitikai intézkedések hatásosságának méréséről ['The "Gyed-Effect": The Impact of the Family Allowance System on Fertility between 1985 and 1996']. Demográfia 51.1: 51-78.

Klinger, András. 1981. "Népesedés - a népesedéspolitika és eszközei." ['Population and the Implementation of Population Policy.'] Társadalmi Szemle 3.: 20-32.

Kolosi, Tamás and Fábián, Zoltán. 2016. "Wealth Distribution in Hungary." Hungarian Social Report. Budapest: TÁRKI, 13. http://old.tarki.hu/hu/publications/SR/2016/trip2016_resumes.pdf

Kolosi, Tamás and Pósch, Krisztián. 2019. "Social Classes and the Self-Image of Society." Központi Statisztikai Hivatal ['Hungarian Central Statistical Office'], vital statistics, 1960-2012 http://www.ksh.hu/docs/eng/xstadat/xstadat_annual/i_wnt001b.html https://en.wikipedia.org/wiki/Demographics_of_Hungary\#cite_note-63

Makay, Zsuzsanna. 2015. "Family Support System - Childraising - Employment." Demographic Portrait of Hungary 2015. Eds. J. Monostori, P. Öri, Zs. Spéder. Budapest: HDRI, 57-74. https://demografia.hu/en/publicationsonline/index.php/demographicportrait/article/view/8 $\underline{85 / 647}$

Makay, Zsuzsanna. 2019. "Reform of the Hungarian Family Policy System: Are Employed Parents the Main Beneficiairies?" Hungarian Demographic Research Institute. Leave network workshop 30.08.2019:1-34.

Makszin, Kristin and Bohle, Dorothee. 2020. "Housing as a Fertility Trap: The Inability of States, Markets, or Families to Provide Adequate Housing in East Central Europe." East European Politics and Societies and Cultures 20.10: 1-25. http://online.sagepub.com

Mrav, Noemi. 2018. "Már a diplomás magyarok 8 százaléka él és dolgozik külföldön” ['Eight Percent of Graduates Live and Work Abroad']. The Budapest Beacon https://xpatloop.com/channels/2018/11/hungary-leads-in-brain-drain-statistic.html https://hu.euronews.com/2018/11/07/mar-a-diplomas-magyarok-8-szazaleka-el-esdolgozik-kulfoldon in Hungarian Social Report.2018:142. Budapest:Tárki. MTI-Hungary Today 2019.05.22. Women with Four Children to Be Income-tax Exempt from 2020 - Hungary Today

OECD. 2018."Hungary" in International Migration Outlook 2018. OECD publication. Paris. https://doi.org/10.1787/migr_outlook-2018-21-en

Rat, Crsitina and Szikra, Dorottya. 2018. "Family Policies and Social Inequalities in Central and Eastern Europe: A Comparative Analysis of Hungary, Poland and Romania Between 2005 and 2015." Handbook of Family Policy. Eds. Guðný Björk Eydal and Tine Rostgaard. Cheltenham: Edward Elgar Publishing, 223-235.

Romsics, Ignác. 1999. Magyarország Története a XX. Században ['History of Hungary in the Twentieth Century']. Budapest: Osiris.

Sarnyai, Gábor. 2018:Inside Hungary's Family Support System | NewsPortal.HU:12.10.2018).

Spéder, Zsolt, Murinkó, Lívia and Oláh Sz.,Lívia. 2017. "Sailing close ot the wind? The effects of third birth policies in post-communist Hungary". Working papers on Population, Family and Welfare. 29.2-27. Budapest: Demographic Research Inst. 
Szántó, Ildikó. "Child and Family Benefits to Halt Hungary’s Population Decline, 1965-2020: A Comparison with Polish and Romanian Family Policies." Hungarian Cultural Studies. e-Journal of the American Hungarian

Educators Association, Volume 14 (2021): http://ahea.pitt.edu DOI: 10.5195/ahea.2021.429

Spéder, Zsolt, Murinkó, Lívia and Oláh Sz., Livia. 2020. "Cash Support vs. Tax Incentives:The Differential Impact of Policy Interventions on Third Births in Contemporary Hungary." Population Studies: A Journal of Demography 74.1: 39-54.

Szikra, Dorottya. 2011. "Tradition Matters: Child Care and Primary School Education in Modern Hungary" Children, Families and States. Time Policies of Childcare, Preschool, and Primary Education in Europe. Eds. K. Hagemann, K. Jarausch, C. Allemann-Ghionda. New York: Berghahn, 364-384.

-------. 2014. "Democracy and Welfare in Hard Times: The Social Policy of the Orbán Government in Hungary Between 2010 and 2014." Journal of European Social Policy 24.5: $1-15$.

------. 2018. "Welfare for the Wealthy." The Social Policy of the Orbán Regime, 2010-2017." Budapest: Friedrich Ebert Stiftung, 1-12. https://library.fes.de/pdffiles/bueros/budapest/14209.pdfhttps://library.fes.de/pdf-files/bueros/budapest/14209.pdf

Szántó, Ildikó. 2014. "Problems of a Declining Hungarian Birth Rate: A Historical Perspective" AHEA. https://ahea.net/conferences/2014/papers/submittedpapers?memberpapersuser $=\mathrm{Sz} \% \mathrm{E} 1 \mathrm{nt} \% \mathrm{~F} 3 \% 2 \mathrm{C}+\mathrm{Ildik} \% \mathrm{~F} 3 \&$ memberpaperstopic=History

-------. 2015. "Declining Hungarian Birth Rate Seen in Hungarian Literature." AHEA. https://ahea.net/conferences/2015/submittedpapers?memberpapersuser $=\mathrm{Sz} \% \mathrm{E} 1 \mathrm{nt} \% \mathrm{~F} 3 \% 2 \mathrm{C}+\mathrm{Ildik} \% \mathrm{~F} 3 \&$ memberpaperstopic=History

Thévenon, Olivier. 2011. Family Policies in OECD Countries: A Comparative Analysis. Population and Development Review 37.1: 57-87. https://onlinelibrary.wiley.com/doi/abs/10.1111/j.1728-4457.2011.00390.x

The World Bank. Hungary: Unemployment Rate. https://www.theglobaleconomy.com/Hungary/Unemployment_rate/

Walker, Shaun. 2020. "Baby Machines': Eastern Europe's Answer to Depopulation.” The Guardian. https://www.theguardian.com/world/2020/mar/04/baby-bonuses-fit-thenationalist-agenda-but-do-they-work. March 4, 2020.

Waterbury, Myra A. 2020. "Populist Nationalism and the Challenges of Divided Nationhood: The Politics of Migration, Mobility, and Demography in Post-2010 Hungary" East European Politics and Societies and Cultures 20. 20: 1-22. http://online.sagepub.com

Vég, Márton. 2019. "Ez az igazi migráció: már minden hatodik magyar külföldön születik" ['This is the Real Emigration: Every Sixth Hungarian Is Born Abroad']. 444.hu https://hu.euronews.com/2019/04/10/minde-hatnodik-magyar-gyerek-kulfoldon-szuletik 
Szántó, Ildikó. "Child and Family Benefits to Halt Hungary’s Population Decline, 1965-2020: A Comparison with Polish and Romanian Family Policies." Hungarian Cultural Studies. e-Journal of the American Hungarian

Educators Association, Volume 14 (2021): http://ahea.pitt.edu DOI: 10.5195/ahea.2021.429

\section{Appendix}

Table 1 Population of Hungary (1900-2020)

Total fertility rates Historical

\begin{tabular}{|cc|cc|}
\hline Year & Total Fertility Rate & Year & Total Fertility Rate \\
\cline { 2 - 4 } $1900-1901$ & 5.28 & $1971-1975$ & $2.10 \mathbf{\Delta}$ \\
$1910-1911$ & $4.67 \boldsymbol{\nabla}$ & $1976-1980$ & $2.09 \boldsymbol{\nabla}$ \\
$1920-1921$ & $3.84 \boldsymbol{\nabla}$ & $1981-1985$ & $1.79 \boldsymbol{\nabla}$ \\
$1930-1931$ & $2.84 \boldsymbol{\nabla}$ & $1986-1990$ & $1.80 \mathbf{\Delta}$ \\
$1940-1941$ & $2.48 \boldsymbol{\nabla}$ & $1991-1995$ & $1.70 \boldsymbol{\nabla}$ \\
$1948-1949$ & $2.56 \mathbf{\Delta}$ & $1996-2000$ & $1.35 \mathbf{\nabla}$ \\
$1950-1955$ & $2.73 \mathbf{\Delta}$ & $2001-2005$ & $1.29 \boldsymbol{\nabla}$ \\
$1956-1960$ & $2.24 \boldsymbol{\nabla}$ & $2006-2010$ & $1.31 \mathbf{\Delta}$ \\
$1961-1965$ & $1.83 \boldsymbol{\nabla}$ & $2011-2015$ & $1.35 \mathbf{\Delta}$ \\
$1966-1970$ & $1.99 \mathbf{\Delta}$ & $2016-2020$ & $1.50 \mathbf{\Delta}$ \\
\hline
\end{tabular}

Source: Mek.niif.hu. "STADAT-1.1. Population, vital statistics (1949-)". portal.ksh.hu. 22.1.1.1. Main indicators of population and vital events (ksh.hu)

Table 2 Hungary - Historical Fertility Rate Data

Total fertility rate

\begin{tabular}{|c|c|c|c|c|c|c|c|c|c|c|c|c|c|c|c|c|c|c|}
\hline \multicolumn{19}{|c|}{ Total fertility rate in Hungary } \\
\hline 195 & 195 & 196 & 196 & 196 & 196 & 196 & 196 & 196 & 196 & 196 & 196 & 197 & 197 & 197 & 197 & 197 & 197 & 197 \\
\hline 8 & 9 & 0 & 1 & 2 & 3 & 4 & 5 & 6 & 7 & 8 & 9 & 0 & 1 & 2 & 3 & 4 & 5 & 6 \\
\hline 2.2 & 2.1 & 2.0 & 1.9 & 1.7 & 1.8 & 1.8 & 1.8 & 1.8 & 2.0 & 2.0 & 2.0 & 1.9 & 1.9 & 1.9 & 1.9 & 2.3 & 2.3 & 2.2 \\
\hline 3 & 2 & 2 & 9 & 9 & 2 & 0 & 1 & 8 & 1 & 6 & 3 & 7 & 2 & 4 & 5 & 0 & 8 & 6 \\
\hline 1977 & 1978 & 1979 & 1980 & 1981 & 1982 & 1983 & 1986 & 1987 & 1988 & 1989 & 1990 & 1991 & 1992 & 1995 & 1996 & 1997 & 1998 & 1999 \\
\hline 2.17 & 2.08 & 2.03 & 1.92 & 1.88 & 1.78 & 1.73 & 1.83 & 1.79 & 1.78 & 1.78 & 1.84 & 1.85 & 1.76 & 1.57 & 1.45 & 1.37 & 1.33 & 1.29 \\
\hline 200 & 200 & 200 & 200 & 200 & 200 & 200 & 200 & 200 & 200 & 201 & 201 & 201 & 201 & 201 & 201 & 201 & 201 & 201 \\
\hline 0 & 1 & 2 & 3 & 4 & 5 & 6 & 7 & 8 & 9 & 0 & 1 & 2 & 3 & 4 & 5 & 6 & 7 & 8 \\
\hline 1.3 & 1.3 & 1.3 & 1.2 & 1.2 & 1.3 & 1.3 & 1.3 & 1.3 & 1.3 & 1.2 & 1.2 & 1.3 & 1.3 & 1.4 & 1.4 & 1.5 & 1.5 & 1.5 \\
\hline 2 & 1 & 0 & 7 & 8 & 1 & 4 & 2 & 5 & 2 & 5 & 3 & 4 & 5 & 4 & 5 & 3 & 4 & 5 \\
\hline
\end{tabular}

Source: Hungary Fertility Rate 1950-2021 | MacroTrends 
Szántó, Ildikó. "Child and Family Benefits to Halt Hungary’s Population Decline, 1965-2020: A Comparison with Polish and Romanian Family Policies." Hungarian Cultural Studies. e-Journal of the American Hungarian

Educators Association, Volume 14 (2021): http://ahea.pitt.edu DOI: 10.5195/ahea.2021.429

Table 3 Wealth distribution in Hungary, 2015: a macro estimation

\begin{tabular}{|l|l|}
\hline Wealth strata & Percent of households \\
\hline $\begin{array}{l}\text { Fortuneless (less than 7 million } \\
\text { HUF assets) }\end{array}$ & $50 \%$ \\
\hline Global middle stratum & $45 \%$ \\
\hline $\begin{array}{l}\text { (between } 7 \text { and } 70 \text { million HUF } \\
\text { assets) }\end{array}$ & $5 \%$ \\
\hline $\begin{array}{l}\text { Wealthy (over } 70 \text { million HUF } \\
\text { assets) }\end{array}$ & $4,4 \%$ \\
\hline $\begin{array}{l}\text { Within the wealthy stratum } \\
70-150 \text { million HUF assets }\end{array}$ & $0,3 \%$ \\
\hline $150-300$ million HUF assets & $0,3 \%$ \\
\hline 300 million HUF -3 billion HUF & $150-200$ households \\
\hline Over 3 billion HUF
\end{tabular}

Source:Kolosi and Fábián, 2016. "Wealth Distribution in Hungary." Hungarian Social Report. Budapest: Tárki, 13.

Table 4 The Class Map, Hungary, 2014

- upper middle class $2 \%$

- middle class $27 \%$

- lower middle class $22 \%$

- working class $37 \%$

- underclass $12 \%$

Based on Bourdieuan concepts of capital, See Ferge, 2019: 82.

- Elite........................2\% (cca. 200000 inhabitants)

- Upper middle class......... 10.5\% (< 1 million inhabitants $)$

- "Yuppie"................................ 6\% (cca. half million inhabitants )

- Rural middle class................. 7\% (6-700.000 inhabitants)

- Lower middle class ............. 17\%, (cca. 1.5 million inhabitants)

- Workers..................... 16.5\% (cca. 1.5 million inhabitants)

- "Drifters"................................18\%, (1.6-1.7 million inhabitants)

- Underclass............................ 23\% (over 2 million inhabitants)

Source:TÁRKI Social Research Institute, 2014: 98. Ferge. 2019: 82. 
Szántó, Ildikó. "Child and Family Benefits to Halt Hungary’s Population Decline, 1965-2020: A Comparison with Polish and Romanian Family Policies." Hungarian Cultural Studies. e-Journal of the American Hungarian

Educators Association, Volume 14 (2021): http://ahea.pitt.edu DOI: 10.5195/ahea.2021.429

Table 5 The real values index of GYED, GYES and the family allowance, 2010-2016

\begin{tabular}{|l|c|c|c|}
\hline Year & $\begin{array}{c}\text { GYED, Childcare } \\
\text { benefit }\end{array}$ & $\begin{array}{c}\text { GYES, Childcare } \\
\text { allowance }\end{array}$ & Family allowance \\
\hline 2010 & 100.00 & 100.00 & 100.00 \\
\hline 2011 & 99.30 & 98.00 & 96.6 \\
\hline 2012 & 101.88 & 91.92 & 88.73 \\
\hline 2013 & 106.36 & 90.55 & 86.78 \\
\hline 2014 & 115.30 & 92.17 & 87.73 \\
\hline 2015 & 122.45 & 94.39 & \\
\hline 2016 & 130.53 & 94.01 & \\
\hline $\begin{array}{l}\text { Note: } \\
2010=100 \%\end{array}$ & & & \\
\hline
\end{tabular}

Source: Makay 2019: 27

Table 6 Current types of leaves and benefits for families with young children in the Hungarian family benefit system

Prior to childbirth the mother

\begin{tabular}{|c|c|c|}
\hline Age of the child & Worked & Did not work \\
\hline $0-6$ months & $\begin{array}{l}\text { CSED, Csecsemő-gondozási díj [Baby- } \\
\text { care allowance]: } 70 \% \text { of previous } \\
\text { earnings }\end{array}$ & \\
\hline 6-24 months & $\begin{array}{l}\text { GYEDGyermekgondozási dí [Child- } \\
\text { Care Benefit]: } 70 \% \text { of previous earnings } \\
\text { with an upper limit }\end{array}$ & $\begin{array}{c}\text { GYES } \\
\text { Gyermekgondozási } \\
\text { segély [Child-Care } \\
\text { Allowance]: fixed-sum } \\
\text { benefit }\end{array}$ \\
\hline 24-36 months & $\begin{array}{l}\text { GYES Gyermekgondozási segély } \\
\text { [Child-Care Allowance]: fixed-sum } \\
\text { benefit }\end{array}$ & \\
\hline $3-8$ years & \multicolumn{2}{|c|}{$\begin{array}{l}\text { GYET, Gyermeknevelési támogatás [Child-Rearing Support]: } \\
\text { fixed-sum benefit for families with three or more children }\end{array}$} \\
\hline
\end{tabular}

Source: Makay 2019:19 
Szántó, Ildikó. "Child and Family Benefits to Halt Hungary's Population Decline, 1965-2020: A Comparison with Polish and Romanian Family Policies." Hungarian Cultural Studies. e-Journal of the American Hungarian Educators Association, Volume 14 (2021): http://ahea.pitt.edu DOI: 10.5195/ahea.2021.429

Table 7 Development of expenditure on family support allowances dependent, or not dependent on social security contributions, 2010-2016

\begin{tabular}{|c|c|c|c|c|c|c|c|}
\hline & \multicolumn{3}{|c|}{$\begin{array}{l}\text { Allowances dependent on } \\
\text { insurance contributions }\end{array}$} & \multicolumn{4}{|c|}{$\begin{array}{l}\text { Allowances not dependent on insurance } \\
\text { contributions (universal benefits) }\end{array}$} \\
\hline & CSED & GYED & $\begin{array}{l}\text { Family tax } \\
\text { and social } \\
\text { security } \\
\text { discounts }\end{array}$ & $\begin{array}{l}\text { Family } \\
\text { allowance }\end{array}$ & GYES & GYET & $\begin{array}{l}\text { Maternity grant, } \\
\text { one- off financial } \\
\text { grant }\end{array}$ \\
\hline 2010 & 37.5 & 92.4 & 31.5 & 359.0 & 65.1 & 13.4 & 5.7 \\
\hline 2016 & 49.7 & 128.9 & 284.9 & 313.1 & 62.3 & 11.4 & 5.8 \\
\hline $\begin{array}{l}\text { Differ. } \\
2010- \\
2016 \\
\text { (HUF } \\
\text { bill.) }\end{array}$ & $\begin{array}{l}+ \\
12.2\end{array}$ & $\begin{array}{l}+ \\
36.5\end{array}$ & $\begin{array}{l}+ \\
253.4\end{array}$ & $\begin{array}{c}- \\
45.9\end{array}$ & -2.8 & $\begin{array}{l}- \\
-2.0\end{array}$ & $\begin{array}{l}+0.1 \\
\text { Unchanged for years, } \\
\text { HUF } 64125=180 \text { euros. } \\
\text { Source:HCSO } 2017 \mathrm{~b} \\
2019\end{array}$ \\
\hline
\end{tabular}


Szántó, Ildikó. "Child and Family Benefits to Halt Hungary’s Population Decline, 1965-2020: A Comparison with Polish and Romanian Family Policies." Hungarian Cultural Studies. e-Journal of the American Hungarian

Educators Association, Volume 14 (2021): http://ahea.pitt.edu DOI: 10.5195/ahea.2021.429

Table 8 Decrease of total population: Hungary, KSH. 2019

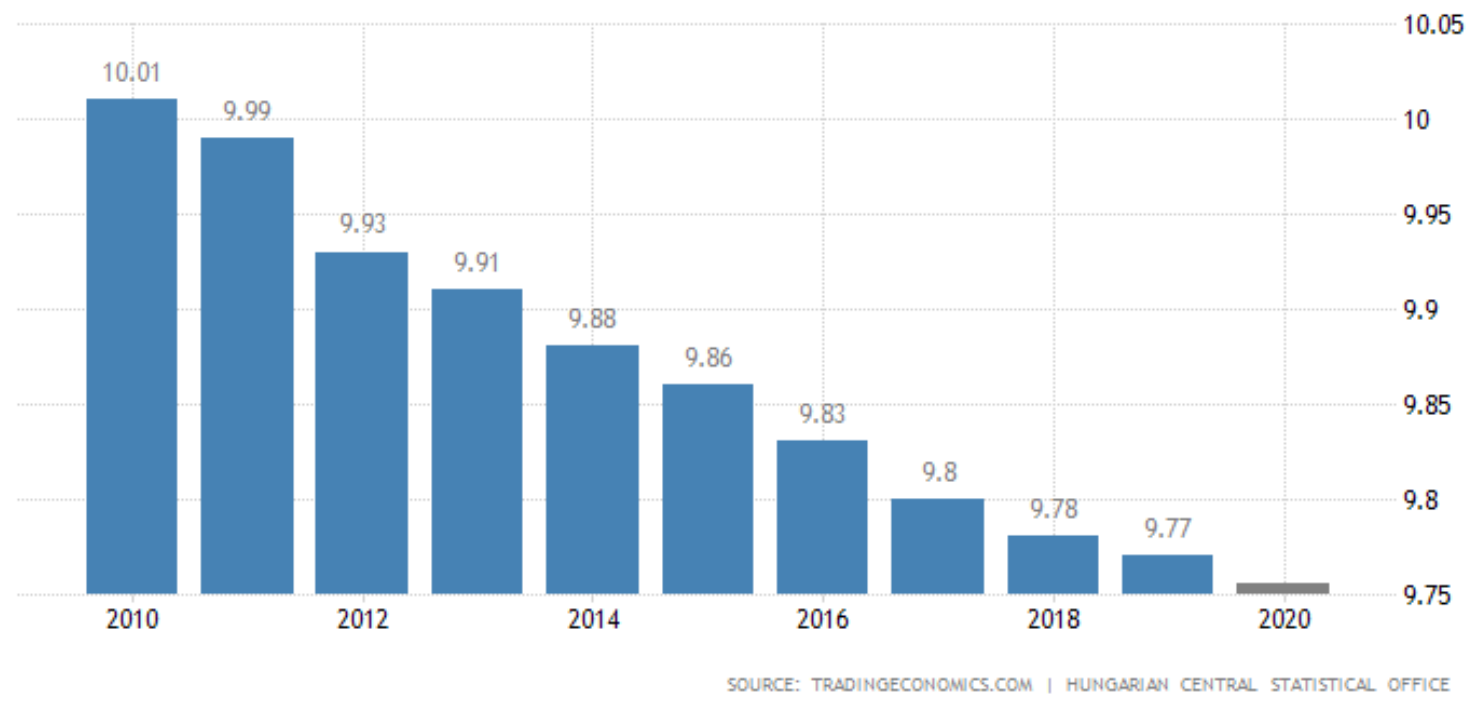


Szántó, Ildikó. "Child and Family Benefits to Halt Hungary’s Population Decline, 1965-2020: A Comparison with Polish and Romanian Family Policies." Hungarian Cultural Studies. e-Journal of the American Hungarian

Educators Association, Volume 14 (2021): http://ahea.pitt.edu DOI: 10.5195/ahea.2021.429

Table 9 Comparison of Hungarian, Polish and Romanian Historical Fertility Rates

\begin{tabular}{|c|c|c|c|c|c|c|}
\hline \multirow{2}{*}{$\begin{array}{l}\text { Year } \\
\\
1950\end{array}$} & \multicolumn{2}{|c|}{$\begin{array}{c}\text { Hungary } \\
\text { Fertility Rate 1950-2020 }\end{array}$} & \multicolumn{2}{|c|}{$\begin{array}{c}\text { Poland } \\
\text { Historical Fertility } \\
\text { Rate }\end{array}$} & \multicolumn{2}{|c|}{$\begin{array}{c}\text { Romania } \\
\text { Historical Fertility Rate }\end{array}$} \\
\hline & Fertility rate & Growth rate & Fertility rate & Growth rate & Fertility rate & Growth rate \\
\hline 1955 & & & 3.566 & $-0.890 \%$ & 2.930 & $-2.170 \%$ \\
\hline 1960 & {$[2.02$} & & 3.170 & $-4.520 \%$ & 2.483 & $-4.830 \%$ \\
\hline 1965 & 1.81 & & 2.566 & $-2.910 \%$ & $\begin{array}{lc} & 2.410 \\
& \mathbf{1 9 6 6} \\
\mathbf{2 . 5 6 2} & \\
\mathbf{1 9 6 7} & \mathbf{2 . 7 1 5} \\
1968 & 2.868 \\
1969 & 2.825\end{array}$ & $\begin{array}{c}6.780 \% \\
\\
\mathbf{6 . 3 1 0 \%} \\
5.970 \% \\
5.640 \% \\
-1.500 \%\end{array}$ \\
\hline 1970 & 1.97 & & 2.295 & $-0.860 \%$ & 2.782 & $-1.520 \%$ \\
\hline 1975 & 2.38 & & 2.232 & $-0.090 \%$ & 2.612 & $-0.800 \%$ \\
\hline 1980 & 1.92 & & 2.2622 & $0.760 \%$ & 2.415 & $-2.660 \%$ \\
\hline 1985 & 1.83 & & 2.253 & $-1.310 \%$ & 2.235 & $0.450 \%$ \\
\hline 1990 & 1.84 & & 2.076 & $-2.030 \%$ & 1.962 & $-7.190 \%$ \\
\hline 1995 & 1.57 & & 1.775 & $-4.620 \%$ & 1.430 & $-2.590 \%$ \\
\hline $\begin{array}{l}2000 \\
2003\end{array}$ & $\begin{array}{l}1.32 \\
1.295\end{array}$ & $\begin{array}{l}-1.200 \% \\
-1.300 \%\end{array}$ & 1.413 & $-3.480 \%$ & 1.308 & - \\
\hline 2004 & 1.27 & & 1.282 & $1.830 \%$ & & $0.300 \%$ \\
\hline 2005 & 1.309 & $0.540 \%$ & 1.305 & $1.790 \%$ & 1.381 & $3.210 \%$ \\
\hline 2010 & 1.330 & $0.000 \%$ & 1.358 & $-0.590 \%$ & 1.510 & $0.000 \%$ \\
\hline 2015 & 1.396 & $2.350 \%$ & 1.368 & $1.260 \%$ & 1.555 & $1.440 \%$ \\
\hline 2019 & 1.501 & $0.670 \%$ & 1.429 & $0.630 \%$ & 1.625 & $0.310 \%$ \\
\hline 2020 & 1.511 & $0.670 \%$ & 1.439 & $0.700 \%$ & 1.631 & $0.370 \%$ \\
\hline
\end{tabular}

Data Source: United Nations - World Population Prospects https://www.macrotrends.net/countries/ROU/romania/fertility-rate

<a href='https://www.macrotrends.net/countries/ROU/romania/fertility-rate'>Romania Fertility Rate 1950-2020</a>. www.macrotrends.net.

Retrieved 2020-06-26. Source:https://knoema.com/atlas/Hungary/topics/Demographics/Fertility/Fertility-rate

https://www.macrotrends.net/countries/HUN/hungary/fertility-rate 